\title{
Arvio mahdollisista nurmibiomassan lähteistä bioenergian raaka-aineeksi Suomessa
}

\author{
Oiva Niemeläinen \\ MTT, Kasvintuotannon tutkimus, E-talo, 31600 Jokioinen
}

\section{Tiivistelmä}

Nurmibiomassasta voidaan tuottaa energiaa mm. polttamalla tai prosessoimalla massa biokaasuksi. Tässä hahmotetaan kuinka paljon nurmibiomassaa olisi saatavissa nykyisellä tuotantorakenteella esim. biokaasun tuotantoon, jos muut bioenergiantuotannon reunaehdot sitä puoltaisivat. Merkittävä ala bioenergian tuotantoon on pellonkäyttökategoriassa "Hoidettu viljelemätön pelto", jonka ala v. 2009 on ollut 130000 ha. Tästä alasta riistapeltoja oli 17000 ha, jolta alalta satoa ei saa korjata pois. Biomassan hyödyntäminen on mahdollista myös viherkesannoilta (43 $000 \mathrm{ha}$ ) ja suojavyöhykkeiltä (7 000 ha). Sellaista peltoalaa, jolta sato voitaisiin hyödyntää on siten runsaat 160000 ha. Tämä on merkittävä määrä suhteessa ruokohelpin nykyiseen viljelyalaan (18 000 ha) bioenergian tuotannossa.

On vaikea arvioida kuinka suuri biomassa muodostuu nykyisin hoidetulla viljelmättömällä pellolla, viherkesannoilla ja suojavyöhykkeillä. Kattavia biomassan arvioita ei ole tehty. Jos alueiden hoito ohjeistettaisiin ja otettaisiin huomioon sekä bioenergian tuotannon tarpeet että ao. ohjelmille asetetut muut tavoitteet huomioon ottaen niin vuosittain biokaasun tuotantoon käytettävisä olevan biomassan määrä voisi olla hyvin merkittävä. Nurmipalkokasvien hyödyntäminen olisi keskeinen tekijä biomasssasadon lisäämisessä. Rehunurmikasveista saataneen normaalin satovaihtelun vuoksi ajoittain ”ylijäämä” säilörehua biokaasulaitosten syötteeksi. Lisäksi syötettä voitaisiin todennäköisesti tuottaa nykyisellä rehunurmialalla hehtaarisatoja lisäämällä, jos syötteen tuottamiseen olisi riittävät taloudelliset kannustimet.

Siemennurmista on muutaman tuhannan hehtaarin alalta korjattavissa puintiolki ja odelmasato bioenergian tuotantoon. Viljojen aluskasveista on mahdollista saada syötettä biokaasun tuotantoon, mutta alhaiset hehtaarisadot rajoittanevat sadonkorjuun kannattavuutta. Italianraiheinästä ja palkokasveista olisi saatavissa suotuisissa olosuhteissa 2000 - $3000 \mathrm{~kg} \mathrm{ka/ha} \mathrm{satoja.} \mathrm{Jos} \mathrm{esimerkiksi}$ aluskasvien ympäristövaikutusten vuoksi halutaan niiden käyttöä lisätä voisi aluskasvien viljelypintaala olla hyvinkin merkittävä (yli 500000 ha). Aluskasveista korjattavissa olevan sadon arviointi edellyttää lisätutkimuksia. Artikkelissa arvioidaan viljelytilaston ja tutkimusten satotietojen pohjalta minkälaisia nurmen tuotantoon perustuvia biomassamääriä ja viljelyaloja olisi mahdollisesti käytettävissä bioenergian tuotantoon. Esitys kartoittaa raaka-ainepotentiaalia ja aiheen tutkimustarvetta.

Asiasanat: bioenergia, biokaasu, biomassa, nurmikasvit, sato, syöte, viherkesanto 


\section{Johdanto}

Erilaiset bioenergian tuotantovaihtoehdot ja -tavat ovat olleet usean elintarviketuotannosta vapautuvan peltoalan käyttöä pohtivan tarkastelun aiheena (kts. mm. Järvenpää ym. 1994, ANON. 2005, ANON. 2007, Latvala ym. 2007). Nurmibiomassa soveltuu bioenergian tuotantoon mm. polttamalla tai prosessoimalla biokaasuksi (kts Prochnow ym. 2009 a ja b). Heinäbiomassoista saadaan biokaasutuksella energiaa noin 3 MWh/ kuiva-ainetonni (Lehtomäki 2006). Prochnowin ym. (2009a) mukaan nurmibiomassojen syötespesifiset metaanisadot nousevat korjuun aikaistuessa, kun taas pintaalaspesifiset metaanisadot nousevat hehtaarikohtaisten biomassasatojen kohotessa. Nurmibiomassat sopivat hyvin biokaasulaitosten syötteeksi vaikkakin nurmimassan käytössä on havaittu teknisiä ongelmia (Prochnowin ym 2009 a).

Työryhmämuistion (ANON. 2007) mukaan kiinnostus biokaasulaitosten rakentamiseen maatiloille lisääntyy jatkuvasti Suomessa. Tässä tarkastelussa keskitytään pohtimaan minkälaisia nurmipohjaisia biomassoja biokaasun syötteeksi on käytettäväksi ja toisaalta minkälaiset mahdollisuudet olisi biokaasusyötteen tuotannon lisäämiseen ilman merkittäviä muutoksia muussa tuotannossa. Huomion kohteena on erityisesti pellon käytön kategoria "Hoidettu viljelemättömän pelto", jonka ala vuonna 2009 on 130000 ha. Syntyneen biomassan korjaaminen on mahdollista muilla tämän peltoluokan kategorioilla kuin "Riistapelto". Biomassan hyödyntäminen on mahdollista myös viherkesannoilta (43 000 ha) ja suojavyöhykkeiltä (7 000 ha) (kts. ANON. 2009). Sellaista peltoalaa, jolta sato voitaisiin hyödyntää on runsaat 160000 ha. Tämä on mittava tuotantoresurssi mm. suhteessa ruokohelpin nykyiseen alaan bioenergian tuotannossa (18 $000 \mathrm{ha}$ ).

Hoidetun viljelemättömän pellon, viherkesannon ja suojavyöhykkeiden käytöllä on vesien suojeluun ja viljelyn monimuotoisuuteen liittyviä tavoitteita. Olisiko ohjelmien eri tavoitteet mahdollista saavuttaa vaikka sato hyödynnettäisiin esim. biokaasun tuotannossa? Muodostuneen biomassan hyödyntämisen kannattavuuteen vaikuttaa olennaisesti biomassan määrä ja käyttöarvo. Lisäksi tarkastellaan mahdollisuuksia tuottaa rehunurmialalta syötettä biokaasun tuotantoon ja aluskasvien tuotantopotentiaalia. Tarkastelu pyrkii luomaan pohjaa pohdinnalle käytettävissä olevan nurmibiomassan määrästä bioenergian, lähinnä biokaasun, raaka-aineeksi.

\section{Aineisto ja menetelmät}

Tarkastelun pohjana on käytetty TIKEn tilastotietoja maatalousmaan käytöstä ja viljelykasvien sadoista sekä niissä, että kirjallisuudessa esitettyjä arvioita hehtaarisadoista.

\section{Tulokset ja tulosten tarkastelu}

\section{Rehunurmet}

Karjatiloilla pyritään nurmiala mitoittamaan niin että nurmista saadaan vähintään rehutarvetta vastaava sato. Nurmisadon vuosittainen vaihtelu tuottaa aika-ajoin tarvetta suuremman sadon. Ylijäämäsato käy hyvin biokaasun syötteeksi. Vuosina 1998-2007 säilörehun keskisato oli 17720 kg/ha ja heinän keskisato 3560 kg/ha (ANON. 2009). Vuosi 2006 oli kuiva ja silloin säilörehun keskisato oli poikkeuksellisen alhainen, vain $13270 \mathrm{~kg} / \mathrm{ha}$, ja säilörehun kokonaissato 28 prosenttia pienempi kuin vuonna 2005 (ANON, 2006, Niemeläinen ym. 2006). Jos säilörehun tuotannossa tähdätään viiden prosentin "varmuusvaraan” riittävän rehutarpeen varmistamiseksi niin vuoden 2008 säilörehun tuotantoalalla 451600 ha kyseessä olisi noin 20000 hehtaarin varaus. Se on samaa kokoluokkaa kuin nykyinen ruokohelpin viljelyala. Vuosina 2008 ja 2007 säilörehun kokonaissatoarvio oli 8,3 mrd kg. Viisi prosenttia siitä on 400 milj. kg säilörehua, jonka kuiva-ainepitoisuus vaihdellee välillä 20-25 prosenttia (kts ANON. 2009). Viiden prosentin ”ylijäämä sato” olisi noin 100 milj. kg ka.

Vuoden 2009 peltoalatilastoissa alle 5-vuotisia rehunurmia oli 634800 ha ja vähintään 5- vuotta vanhoja nurmia 32600 ha (ANON. 2009). Siemennurmia oli 10600 ha ja ruokohelpin viljelyala oli 18100 ha. Säilörehua tuotettiin v. 2008451600 hehtaarilla, laitumina oli 80600 ha, ja heinää tehtiin 102500 hehtaarilta (ANON Tike 11.12.2008).

Nurmikasvien kuiva-ainesatojen arviointi on haasteellista. Etenkin säilörehusadon kuivaainepitoisuus voi vaihdella huomattavasti. Laskemalla TIKEn vuosien 1998-2007 säilörehun ja heinän keskisadot säilörehun 25 prosentin kuiva-ainepitoisuudella ja heinän 83 prosentin kuivaainepitoisuudella saadaan säilörehunurmien kuiva-ainesadoksi $4430 \mathrm{~kg} \mathrm{ka/ha} \mathrm{ja} \mathrm{heinänurmien} \mathrm{kuiva-}$ 
ainesadoksi $2950 \mathrm{~kg} \mathrm{ka/ha.} \mathrm{Säilörehun} \mathrm{kuiva-ainesato} \mathrm{olisi} \mathrm{vajaa} \mathrm{puolet} \mathrm{sadosta,} \mathrm{joka} \mathrm{rehunnurmista}$ on virallisissa lajikekokeissa saatu. Timotein keskimääräinen kuiva-ainesato virallisissa lajikekokeissa oli $9090 \mathrm{~kg} \mathrm{ka} / \mathrm{ha}$ jaksolla 1993-2000 (Tammisto II-lajike). Ensimmäisen niiton sato oli $4692 \mathrm{~kg}$ ka/ha (kts. Kangas ym. 2001). Vuosina 2001-2008 (Tammisto II) keskisato oli 9750 kg ka/ha, josta 1. niitossa $4992 \mathrm{~kg} \mathrm{ka/ha.} \mathrm{Vaikuttaa} \mathrm{ilmeiseltä,} \mathrm{että} \mathrm{normaaleina} \mathrm{kasvukausina} \mathrm{riittävä} \mathrm{nurmirehumäärä}$ saadaan pääosin jo ensimmäisestä korjuusta ja jälkisatoon ei ole ollut tarvetta panostaa. On oletettavaa, että rehunurmien satoisuutta olisi mahdollisuus merkittävästi kohottaa, jos siihen on riittävät kannustimet. Esimerkiksi Hannukkalan (2008) tutkimuksessa timoteinurmen sato Lapissa kivennäismaalla biokaasun raaka-aineeksi viljeltynä oli $11720 \mathrm{~kg} \mathrm{ka} / \mathrm{ha}$. Lajikekokeiden tulosaineisto kuvaa intensiivistä viljelyä. Heinien typpilannoitus lajikekokeissa on kivennäismailla $100 \mathrm{~kg}$ typpeä/ha kahdelle ensimmäiselle niitolle ja kolmannelle niitolle 30 - 40 kg N/ha (ANON. 2008).

Rehunurmien sadon ohella myös siemennurmien olki- ja odelmasato olisi mahdollista hyödyntää biokaasun tuotannon syötteenä, vaikka osa kasvustoita hyödynnetään heinäksi ja säilörehuksi jo nyt. Nurmikasvien siemenviljelyala on noin 10000 hehtaaria. On ilmeistä, että myös heinänurmien odelmasatoa olisi korjattavissa biokaasutuotannon syötteeksi, jos korjuulle olisi taloudelliset perusteet olemassa.

Rehunurmien viljelyä tehostamalla on mahdollisuus mittavaan syötteen tuottoon biokaasuntuotantoa varten. Satotason nouseminen kymmenellä prosentilla tuottaisi runsaat 200 milj. kg kuivaainetta.

\section{Viherkesanto ja hoidettu viljelemätön pelto}

Vuonna 2009 "Hoidettu viljelemättömän pelto" kategoriassa on 130000 ha. Syntyneen biomassan korjaaminen on mahdollista muilla tämän peltoluokan kategorioilla kuin "Riistapelto", jossa sato jätetään riistan laidunnettavaksi (kts. ANON. 2009). Riistapeltoja on 17000 ha. Biomassan hyödyntäminen on mahdollista myös viherkesannoilta (43000 ha) ja suojavyöhykkeiltä (7 000 ha) (kts. ANON. 2009). Sellaista peltoalaa, jolta sato voitaisiin hyödyntää on runsaat 160000 ha. Kuinka suurelta alalta ao. pelloilla sato nykyisin korjataan ei ole tiedossa. Hoidetun viljelemättömän pellon, viherkesannon ja suojavyöhykkeiden käytöllä on vesien suojeluun ja viljelyn monimuotoisuuteen liittyviä tavoitteita, jotka määrittävät pelloilla sallittuja toimenpiteitä. Mm. lannoittaminen ei ole sallittua.

Suurin osa luonnonhoitopelloista on nurmikasvustoja. Nurmikasvusto voi tuottaa suuriakin satoja lannoittamattoman jakson alussa. Muun muassa Pahkalan ym. (1996) agrokuitututkimuksessa nurmet tuottivat kylvön jälkeisenä vuonna lannoittamattomina Jokioisissa 6,4 - 7,6, Vihdissä 8,3 - 9,6 ja Ruukissa 5,8 - 8,8 t ka/ha. Pitkäikäisistä lannoittamattomista nurmista ei satotietoja ole käytettävissä. Hokkanen ja Raatikainen (1977) kartoittivat 1 - 6 vuotta pakettipeltoina olleiden peltojan kasvimassaa Jyväskylän seudulla. Maanpäällistä vihermassaa oli keskimäärin 2735 kg/ha ja lisäksi kuollutta materiaalia $1300 \mathrm{~kg}$ /ha eli maan pinnan yläpuolella olevaa kasvimassaa oli $4000 \mathrm{~kg} / \mathrm{ha}$ (uunikuivana). Raatikaisen ja Raatikaisen (1975) nurmen satoisuutta määrittäneessä tutkimuksessa heinäsato oli keskimäärin $3700 \mathrm{~kg} / \mathrm{ha}$. Heinäpeltojen typpilannoitus oli alle $50 \mathrm{~kg} \mathrm{~N} / \mathrm{ha} / \mathrm{v}$. Jokioisissa korjattiin v. 2009 neljännen vuoden heinänurmen sato ns. luonnonhoitonurmi-hoidolla eli nurmea ei lannoitettu. Timotein sato kahdessa niitossa oli $3012+133$ eli yhteensä $3145 \mathrm{~kg}$ ka/ha ja ruokonadan sato 3762 + 927 eli yhteensä 4689 kg ka/ha (Niemeläinen julkaisematon aineisto).

Viherkesanto- ja viherlannoituskokeissa mielenkiinto on kohdistunut maanpäällisen ja maanalaisen kasvimassan esikasvi- ja lannoitusvaikutukseen. Bioenergian raaka-aineen tuotannossa kiinnostaa korjattavissa oleva maanpäällinen versomassa. Känkäsen ym (2009) mukaan useimmat yksivuotiset kasvustot kasvavat voimakkaasti loppukesän ja alkusyksyn aikana. Esim. virnat kasvattivat kaksinkertaisen versosadon muihin palkokasveihin verrattuna, mutta niiden juurimassa oli vaatimaton puna-apilaan verrattuna. Känkäsen tutkimuksessa ruisvirnan maanpäällinen versomassa oli 6 000-7 $000 \mathrm{~kg} \mathrm{ka/ha,} \mathrm{raiheinän} \mathrm{ja} \mathrm{puna-apilan} \mathrm{seoksella} \mathrm{vajaat} 4000 \mathrm{~kg} \mathrm{ka/ha} \mathrm{ja} \mathrm{kolmannen} \mathrm{vuoden}$ timotei-puna-apilanurmella noin $5000 \mathrm{~kg} \mathrm{ka} / \mathrm{ha}$. Suurin viherlannoituskokeiden kuiva-ainesato, $13000 \mathrm{~kg} \mathrm{ka/ha,} \mathrm{korjattiin} \mathrm{kolmannen} \mathrm{vuoden} \mathrm{vuohenherneestä.} \mathrm{Lannoittamattomissa}$ viherkesannoissa palkokasvit ovat yleensä ylivoimaisia sadontuottajia (Känkänen 2001). 


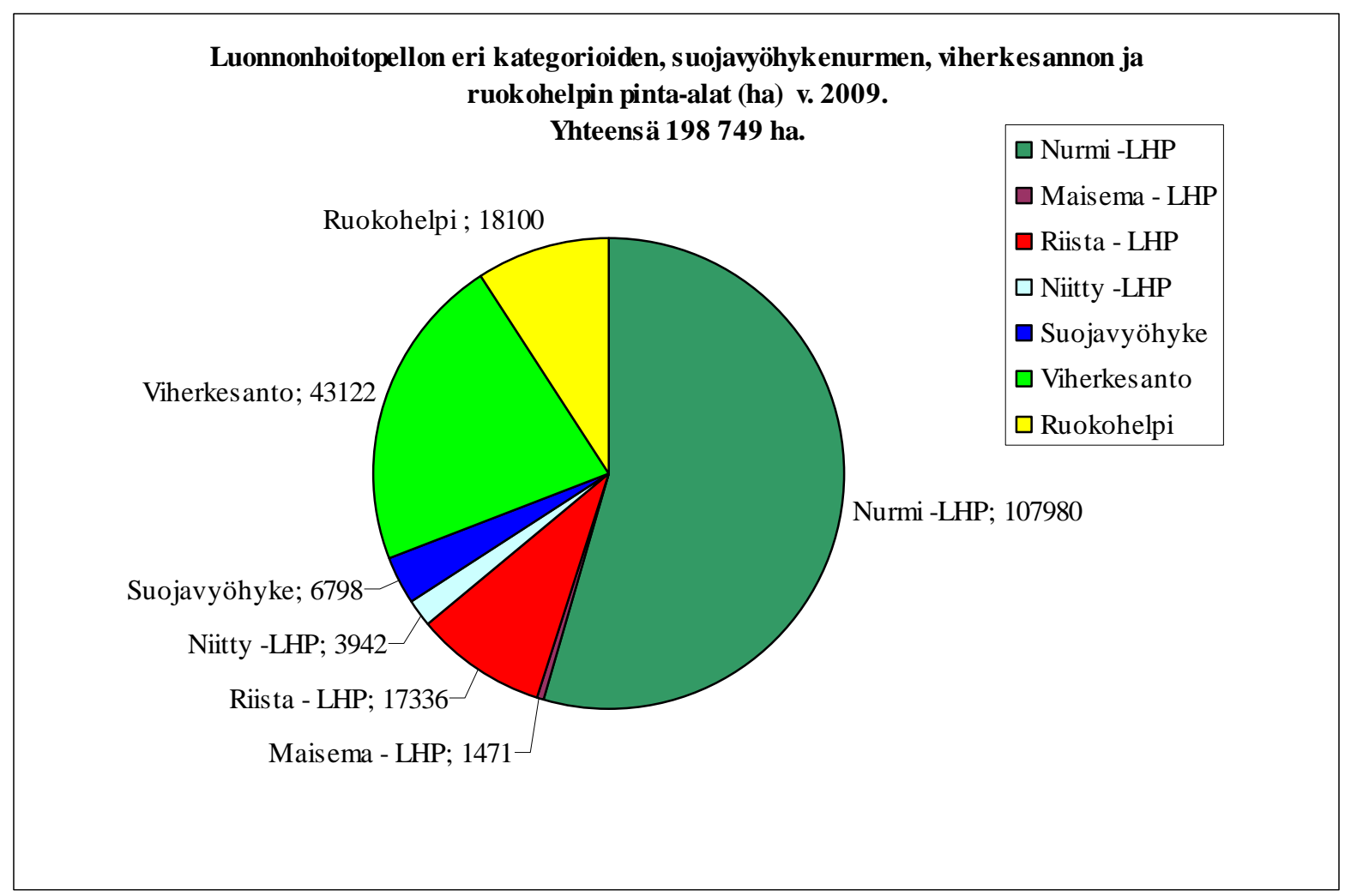

Kuva 1. Pellonkäytön kategoriassa "Hoidettu viljelemätön pelto” oli TIKEn tilaston mukaan v. 2009 yhteensä 130729 ha. Viherkesantona oli 43122 ha ja suojavyöhenurmena 6978 ha. Ruokohelpin viljelyssä oli 18100 ha. Kaikilta muilta käyttömuodoilta kuin riistapellolta on mahdollisuus hyödyntää muodostunut biomassa.(Lähde: TIKE iacs 11.8.2009).

Monivuotisen viherkesannon tai luonnonhoitonurmen satoisuutta voidaan karkeasti hahmottaa nurmipalkokasvien lajikekoetulosten avulla. Nurmipalkokasvit viljellään seoksina heinän kanssa ja kokeiden typpilannoitus on suhteellisen alhainen $-40 \mathrm{~kg} \mathrm{~N} / \mathrm{ha}$ keväällä ja $20 \mathrm{~kg}$ N/ha toiselle niitolle (ANON 2008). Bjursele -lajikkeen keskisato vuosina 1993 - 2000 oli $5617 \mathrm{~kg}$ ka/ha, josta ensimmäisen niiton sato oli $4156 \mathrm{~kg} \mathrm{ka/ha} \mathrm{(Kangas} \mathrm{ym.} \mathrm{2001).} \mathrm{Ensimmäisenä} \mathrm{vuonna} \mathrm{sato} \mathrm{oli} 6$ 481, toisena vuonna 5864 ja kolmantena vuonna $4265 \mathrm{~kg}$ ka/ha eli hehtaarisato pieneni nurmen vanhetessa. Vuosina 2001 - 2008 puna-apilan Bettyn keskisato oli $5281 \mathrm{~kg} \mathrm{ka/ha,} \mathrm{josta} \mathrm{1.} \mathrm{niiton} \mathrm{sato}$ oli $3463 \mathrm{~kg} \mathrm{ka/ha} \mathrm{(Kangas} \mathrm{ym.} \mathrm{2008).} \mathrm{Ensimmäisenä} \mathrm{nurmivuonna} \mathrm{sato} \mathrm{oli} 4631 \mathrm{~kg} \mathrm{ka/ha,} \mathrm{toisena}$ vuonna $5369 \mathrm{~kg} \mathrm{ka/ha} \mathrm{ja} \mathrm{kolmantena} \mathrm{vuonna} 5142 \mathrm{~kg} \mathrm{ka} / \mathrm{ha}$ eli Bettyn satoisuus ei vähentynyt kolmantenakaan vuonna merkittävästi. Valkoapila Sonjan keskisato oli 4875 kg ka/ha, josta ensimmäisen niiton sato $2521 \mathrm{~kg} \mathrm{ka/ha.} \mathrm{Valkoapilan} \mathrm{sato} \mathrm{pysyi} \mathrm{vakaana} 1$ - 3 vuoden aikana 4 691, 5099 ja 5008 kg ka/ha, 1., 2. ja kolmantena nurmivuonna (Kangas ym. 2001). Kesannolla ja luonnonhoitonurmella lannoittaminen ei ole sallittu, joten hehtaarisadot muodostuisivat em. kasveilla yllä mainittuja satoja pienemmiksi.

Kasvimassan korjaaminen luonnonhoitopellolta voi tuoda ympäristöetuja. Vaikka nurmiviljely vähentää eroosioriskiä, se saattaa lisätä liuenneen fosforin kuormaa kevään pintavalunnassa (Turtola 1993, Uusi-Kämppä \& Jauhiainen). Uusi-Kämpän (2007) tutkimuksessa suojavyöhykkeiltä, joilta kasvillisuutta ei niitetty ja korjattu, liuenneen fosforin määrä kasvoi kevään sulamisvesissä. Syynä oli fosforin vapautuminen kasvisoluista. Rädyn ym (2009) tutkimuksessa ensimmäisen syyshallan jälkeen suojavyöhykkeen maanpäällisessä biomassassa havaittiin fosforimäärän vähentyneen jopa $6 \mathrm{~kg} / \mathrm{ha}$. Pintavalumaveteen liuennut fosfori oli peräisin pakkasen rikkomista kasvisoluista ja maan pintakerrokseen kertyneestä fosforista. Niitetyltä nurmikaistalta huuhtoutui vähemmän fosforia kuin niittämättömältä suojakaistalta (Uusi-Kämppä 2007). Fosforikuormitusta voidaan pienentää korjaamalla vuosittain osa maanpäällisestä kasvimassasta. Heinien fosforimäärä oli suurimmillaan kukinnan aikana ja heti sen jälkeen (Uusi-Kämppä \& Kilpinen 2000). Niiton voi olettaa vaikuttavan 
monimuotoisuuteen muuttamalla lajiston runsaussuhteita. Korjuujätteen poisto vähentää pellon ravinteita, joka pitkällä aikavälillä voi suosia lajeja, jotka hyötyvät vähäravinteisesta maaperästä.

Luonnonhoitopelto, viherkesannot ja suojakaistat tarjoavat jo tällä hetkellä merkittävän mahdollisen raaka-ainelähteen biokaasuntuotantoon. Hoitamalla pellot siten, että bioenergian tuotanto maksimoidaan, olisi tältä peltoalalta saatavissa olevaa syötemäärä mahdollista lisätä tuntuvasti. Todennäköisesti monivuotiset nurmipalkokasvit tarjoaisivat tässä varteenotettavia mahdollisuuksia (mm. Sankari 1994). Vuohenherneestä saadut kokemukset sekä meillä (kts. Mäkäräinen ym. 1985, Varis 1986, Virkajärvi ja Varis 1991) että lähialueella (kts. Raig ym. 1991, Lillak ym. 2007, Adamovic ym. 2008) ovat hyvät. Niiden perusteella vuohenherneen ja muiden palkokasvien tuotantoa tulee selvittää biokaasun raaka-aineen tuotannon näkökulmasta. Tästä aiheesta onkin tutkimuksia jo aloitettu (Stoddard ym. 2007).

\section{Ruokohelpi}

Ruokohelven viljelyala bioenergiaksi, polttoaineeksi, oli v. 200918100 ha. Ruokohelven viljelystä ja käytöstä on opaskirjat saatavilla niin tuottajille kuin käyttäjille mm. Lötjönen ym. 2009 ja Lötjönen ja Knuuttila (2009). Lötjösen ym. (2009) mukaan ruokohelpin realistinen sato on 4 - 7 tn ka /ha kun korjuutappiot kevätkorjuussa otetaan huomioon. Pelloilta on saatu 10 tn ka/ha satoja, mutta toisaalta erityisesti nuoret kasvustot ovat tuottaneet vain 3 tn ka/ha. Ruokohelven viljelyn laajentamismahdollisuuksia ja taloudellista kannattavuutta on tarkastelleet mm. Latvalan ym. (2007).

\section{Viljojen aluskasvit}

Viljojen aluskasvikokeissa on selvitetty lähinnä aluskasvien esikasvivaikutusta. Kauppilan (1985) Viikin kokeissa aluskasvien maanpäällisen kasvimassan määrä oli korkeimmillaan $3590 \mathrm{~kg}$ ka/ha persian- ja alsikeapilan seoksella ja $2330 \mathrm{~kg} \mathrm{ka/ha} \mathrm{italianraiheinällä.} \mathrm{Viljelykasvina} \mathrm{oli} \mathrm{aikainen} \mathrm{ohra.}$ Känkäsen (2001) mukaan nurmipalkokasvien kilpailuvaikutus oli pieni, yleensä korkeintaan 200 $\mathrm{kg} / \mathrm{ha}$, kuten myös monivuotisten heinien vaikutus oli vähäinen, mutta italianraiheinä pienensi viljan jyväsatoa keskimäärin 450 - $600 \mathrm{~kg} / \mathrm{ha}$. Aluskasveista olisi mahdollisesti saatavissa suhteellisen suuri sato kokoviljasäilörehuksi korjatun viljan jälkeen (kts. Niemeläinen ym. 2007). Ao. tuotantotilanteessa aluskasvisadon hyödyntäminen laiduntamalla tai niittoruokintana lienee järkevämpää kuin sadon korjaaminen biokaasun syötteeksi.

Viljojen aluskasvein käyttö mahdollistaisi potentiaalisesti suuren tuotantoalan nurmibiomassan tuottamiseen. Tiken 24.11.2009 tietojen mukaan leipäviljaa viljeltiin 232400 hehtaarilla ja mallasohraa 152100 hehtaarilla. Niillä aluskasvien viljely on epätodennäköistä aluskasvien mahdollisen viljasatoa alentavan vaikutuksen vuoksi, vaikka mallasohralle aluskasvit voisivat muuten hyvin sopiakin. Rehuohra oli 409600 ha, kauraa 321900 ha ja seosviljaa 23400 ha eli yhteensä runsaat 750000 ha. Rehuviljaa käytetään monivuotisten nurmien suojaviljoina, ja kun rehunurmia oli v. 2009634800 ha, niin suojaviljaan perustettuja uusia nurmia lienee 150000 - 210000 ha (1/4-1/3 osa rehunurmien pinta-alasta). Rehuviljan viljelyalasta on siten runsaat 500000 ha sellaista alaa, jolla olisi periaatteessa mahdollista viljellä aluskasveja biokaasutuotannon syötteeksi. On todennäköistä, että suurin osa rehuviljojen aluskasvustoista tuottaisi niin pienen hehtaarisadon, että korjuu bioenergiaksi ei olisi tarkoituksenmukaista. Ilmaston muutoksen vaikutuksesta syyskesän sään muuttuu lämpimämmäksi. Tämä saattaa lisätä aluskasveiksi sopivien yksivuotisten nurmi- ja nurmipalkokasvien satoa, koska ne eivät reagoi päivänpituuden lyhenemisiin yhtä voimakkaasti kuin talvehtivat nurmikasvit.

Aluskasvien viljelyn lisääminen olisi teknisesti helppo toteuttaa. Mikkolan (2001) tutkimuksessa kylvö-lannoituskoneen taakse asennettavalla heinänsiemenen kylvölaitteella onnistuttiin perustamaan tavoitteet täyttävä aluskasvusto kaikkina neljänä koevuonna kuiva kasvukausi mukaan luettuna. Aluskasvin kylvöstä aiheutuu menetelmää käyttäen hyvin vähän lisätyötä ja kylvölaitekin on edullinen. Ongelmia saattaa aiheuttaa suorakylvön yleistyminen. Leutoina talvina italianraiheinä voi talvehtia, ja lohkolla voi olla voimakas nurmikasvusto seuraavana kesänä.

\section{Johtopäätökset}

Hoidetuilla viljelemättömillä pelloilla ja viherkesannoilla muodostuu vuosittain mittava määrä biomassaa, joka voitaisiin käyttää syötteenä biokaasun tuottamiseen. Näiden peltojen osalta tulisi selvittää minkäsuuruinen ja -laatuinen biomassa pelloille muodostuu voimassa olevilla hoito- 
ohjeistuksilla. Lisäksi biomassan korjuun vaikutukset ravinnevirtoihin ja kasvilajiston monimuotoisuudelle tulisi selvittää. Bioenergian tuotantoon soveltuville aloille tulisi tuottaa hoitoohjeistus biomassan tuotantoa varten siten, että samalla saavutetaan ohjelmille asetetut muut tavoitteet.

Rehunurmien satovaihtelun vuoksi on oletettavaa, että ajoittain muodostuu "ylijäämä” säilörehua, joka sopisi biokaasun syötteeksi. Myös rehunurmien hehtaarisatojen kohottamiseen on mahdollisuuksia, jos siihen on taloudelliset kannustimet. Viljan aluskasveista olisi saatavissa syötettä biokaasun tuotantoon, mutta nurmibiomassojen käytön kannattavuus bioenergian tuotantoon riippuu politiikkaratkaisuista. Edellämainitut selvitykset antaisivat asiantuntemuspohjaa sekä politiikkaratkaisujen tekemiseksi, että bioenergian tuotantotilanteita varten, jos ne osoittautuvat toteuttamiskelpoisiksi.

\section{Kiitokset}

Kiitokset MMM:n Tietopalvelukeskukselle listauksen toimittamisesta ”Hoidettu viljelemätön pelto” pinta-alatiedoista.

\section{Kirjallisuus}

Adamovics, A. , Dubrovskis, V., Plume, I. \& V. Auzins. 2008. Usage of fodder galega biomass for the biogas production. In Renewable Energy Resources, Production and Technologies. Proceedgins og the $5^{\text {th }}$ UEAA General Assembly and the Associated Workshops, Riga, Latvia, 28-31 May, 2008. Zinatne Publisher. ISBN 9789984-808-31-4. pp 30-36.

ANON. 2005. Peltoviljelyn tulevaisuuden linjaukset Suomessa. Työryhmämuistio 2005:15. Helsinki 2005. 44 p. Saatavilla: http://wwwb.mmm.fi/julkaisut/tyoryhmamuistiot/2005/trm2005_15.pdf

ANON. 2006 ja 2009. Viljelykasvien sato vuonna 2006; 2008. TIKE. 14.12.2006; päivitetty 15.1.2007 ja 29.1.2009. Saatavilla:

http://www.mmmtike.fi/fi/index/tilastojatietopalvelut/tilastot/peltokasvitilastot.html

ANON. 2007. Peltobiomassa, liikenteen biopolttonesteet ja biokaasujaosto. Loppuraportti, Helsinki 20007. Työryhmämuistio mmm 2007:2. Saatavilla: http://www.mmm.fi/attachments/mmm/julkaisut/tyoryhmamuistiot/2007/5lYTgDdW9/trm2007_2.pdf ANON. 2008. Käytössä oleva maatalousmaa 2008. Tike 11.12.2008. Saatavilla: http://www.matilda.fi/pls/portal30/rpportal.matilda_julkaisut.showfile?docid=826\&versio=1259052157\&fileid= $\underline{7749}$

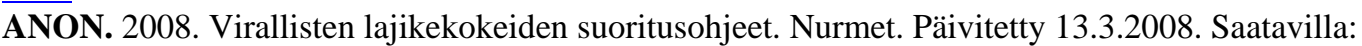
https://portal.mtt.fi/portal/page/portal/mtt/maaseutuyritys/palvelut/kasvintuotanto/virallisetlajikekokeet/lajikekok eidentoteuttaminen/SUORITUSOHJEETWWW_0.pdf

ANON. 2009. Hakuopas. 2009. Tilatuki, Maatalouden ympäristötuki, Luonnonhaittakorvaus, Kansalliset tuet. Maaseutuvirasto. Elektroninen julkaisu. 148 p. Saatavilla:

http://www.mavi.fi/fi/index/viljelijatuet/oppaatjaohjeet/hakuopas.html

ANON. 2009. Rehutaulukot. Saatavilla: https://portal.mtt.fi/portal/page/portal/Rehutaulukot

ANON. 2009. Käytössä oleva maatalousmaa 2009 -TEK ennakkoarvio 23.6.2009. Saatavilla:

http://www.matilda.fi/pls/portal30/rpportal.matilda_julkaisut.showfile?docid=826\&versio=1259052157\&fileid= 7854

Hokkanen, H. \& M. Raatikainen, 1977. Yield, vegetation and succession in reserved fields in Central Finland. J. Sci. Agric. Soc. Finland 49: 221-238.

Hannukkala, A. 2008. Lappiin soveltuvia bioenergiakasveja. MTT:n selvityksiä 159. 21 p. Saatavilla: http://www.mtt.fi/mtts/pdf/mtts159.pdf

Järvenpää, M., H. Sankari, L. Tuunanen \& T. Maunu. 1994. Bioenergian tuotanto elintarviketuotannosta vapautuvalla peltoalalla. Työtehoseuran julkaisuja 333. 109 p.

Kangas, A., A. Laine, M. Niskanen, Y. Salo, M. Vuorinen, L. Jauhiainen \& L. Mäkelä. 2001. Virallisten lajikekokeiden tulokset 1993-2000. MTT:n julkaisuja. Sarja A 94: 262 p. Saatavilla: http://www.mtt.fi/asarja/pdf/asarja94.pdf

Kangas, A., A. Laine, M. Niskanen, Y. Salo, M. Vuorinen, L. Jauhiainen \& H. Nikander. 2008. Virallisten lajikekokeiden tulokset 2001-2008. 196 p. Saatavilla: http://www.mtt.fi/mtts/pdf/mtts167.pdf

Kauppila, R. 1985. Aluskasvien käyttö viljan viherlannoituksessa. Teoksessa: Apilat aluskasveina viljanviljelyssä. Suomen Itsenäisyyden Juhlavuoden 1967 Rahasto. Julkaisu 20. pp. 1-38.

Känkänen, H. 2001. Biomassan ja typen tuotanto sekä viljasadot. Teoksessa: Viherkesannot ja aluskasvit viljan viljelyssä. MTT:n julkaisuja Sarja B. 25. 8-12. Saatavilla: http://mttinfo.mtt.fi/bsarja/pdf/bsarja25.pdf

Känkänen, H., M. Kymäläinen, ja A. Nykänen. 2009. Viherlannoituksesta enemmän tehoa. Maaseudun tiede 3/2009. 26.10.2009. p. 4. 
Latvala, T., E. Aro-Heinilä, R. Toivonen \& E. Järvinen. 2007. Bioenergian tuotanto ja markkinat vuonna 2007 sekä kehitysnäkymät vuoteen 2015. Pellervon taloudellisen tutkimuslaitoksen raportteja N:o 205.70 p. Lehtomäki, A. 2006. Biogas Production from Energy Crops and Crop Residues. Jyväskylä Studies in Biological and Environmental Science 163. Academic Dissertation. Jyväskylä: University of Jyväskylä, 91 p.

Lillak, R., P. Viil, H. Meripold, T. Vosa, I. Kodis \& T. Laidna. 2007. Potential of Galega orientalis as energy crop. . Teoksessa: NJF Seminar 405 Production and Utilization of Crops for Energy. Vilnius, Lithuania, 2526.9.2007. NJF Report Vol. 3, No 4, 2007. pp. 28-30.

Lötjönen, T. \& K. Knuuttila 2009. Pelloilta energiaa - opas ruokohelven käyttäjille. Jyväskylä Innovation ja Maa- ja elintarviketalouden tutkimuskeskus. Jyväskylä. 2009. 42 p.

Lötjönen, T., K. Pahkala, P. Vesanto \& M. Hiltunen 2009. Reed canary grass in Finland. Teoksessa: Energy from field energy crops - a handbook for energy producers. Jyväskylä Innovations \& MTT Agrifood Research Finland. Jyväskylä. pp.14-23.

Mikkola, H. 2001. Aluskasvien kylvötekniikka. MTT:n julkaisuja Sarja B. No 25. Viherkesannot ja aluskasvit viljan viljelyssä. Toim. Hannu Känkänen. pp. 37-41.

Mäkäräinen, E., Kansan, P., Kortesmaa, T. \& E. Varis. 1985. Rehuvuohenherneen viljelyominaisuudet ja käyttöarvo. Suomen Itsenäisyyden Juhlavuoden 1967 Rahasto. Julkaisu 14. 72 p.

Niemeläinen, O., M. Niskanen, L. Jauhiainen. 2006. Kuivuus kuritti nurmia - kokonaissadot silti paikoin hyviä. Koetoiminta ja käytäntö 63, 4(18.12.2006).

Niemeläinen, O., L. Jauhiainen, M. Kontturi, O. Nissinen, M. Vuorinen \& M. Niskanen. 2007. Undersown catch crops as a source of biomass for energy. Teoksessa: NJF Seminar 405 Production and Utilization of Crops for Energy. Vilnius, Lithuania, 25-26.9.2007. NJF Report Vol. 3, No 4, 2007. pp. 109-110.

Pahkala, K., Mela, T., Hakkola, H., Järvi, A. \& Virkajärvi, P. 1996. Agrokuidun tuotanto ja käyttö Suomessa. Tutkimuksen loppuraportti, I osa. Agrokuitukasvien viljely. Maatalouden tutkimuskeskuksen julkaisuja. Sarja A. $3.68 \mathrm{~s}$.

Prochnow, A., Heiermann, M., Phlöchl, M., Linke, B., Idler, C., Amon, T. \& P.J. Hobbs. 2009a. Bioenergy from permanent grassland - A review: 1. Biogas. Bioresource Technology 100: 4931-4944.

Prochnow, A., Heiermann, M., Phlöchl, M., Linke, B., Idler, C., Amon, T. \& P.J. Hobbs. 2009b. Bioenergy from permanent grassland - A review: 2. Combustion. Bioresource Technology 100: 4931-4944.

Raatikainen, M. \& T. Raatikainen, 1975. Heinänurmien sato, kasvilajikoostumus ja sen muutokset. Annales Agriculturae Fenniae 14. 57-191.

Raig, H., Nommasalu, H., Meripold, H., \& J. Metlitskaja. 2001. Fodder galega. Estonian Research Institute of Agriculture. 141 p.

Räty, M., Uusi-Kämppä, J., Yli-Halla, M., Rasa, K. \& Pietola, L. 2009. Phosphorus and nitrogen cycles in the vegetation of differently managed buffer zones. Nutrient Cycling in Agroecosystems DOI 10.1007/s10705009-9277-4

Sankari, H. 1994. Bioenergian tuotantoon soveltuvat peltokasvit. Teoksessa: Bioenergian tuotanto elintarviketuotannosta vapautuvalla peltoalalla. Työtehoseuran julkaisuja 333. pp. 10-48.

Stoddard, F., J. Helenius, P. Mäkelä, E. Niemi, M. Seppänen \& M. Turakainen. 2007. Role of legumes in bioenergy production. Teoksessa: NJF Seminar 405 Production and Utilization of Crops for Energy. Vilnius, Lithuania, 25-26.9.2007. NJF Report Vol. 3, No 4, 2007. pp. 26-27.

Turtola, E. 1993. Phosphorus and nitrogen leaching during set-aside. Proceedings of NJF-seminar no. 228 : Soil Tillage and Environment : Jokioinen, Finland, June 8-10, 1993. NJF-Utredning. Rapport 88: 207-217 Uusi-Kämppä. J. \& M. Kilpinen. 2000. Suojakaistat ravinnekuormituksen vähentäjinä. Maatalouden tutkimuskeskuksen julkaisuja Sarja A 83. 49 p.

Uusi-Kämppä, J. 2007. Effects of freezing and thawing on DRP losses from buffer zones. In: Heckrath, G., Rubæk, G.H. \& Kronvang, B. (eds.). Diffuse phosphorus loss, Risk assessment, Mitigation Options and Ecological Effects in River Basins. The 5th Phosphorus Workshop (IPW5), 3-7 September 2007, Silkeborg, Denmark. DJF Plant Science No. 130. Tjele: Aarhus Universitet: Faculty of Agricultural Sciences. pp. 169-172. Uusi-Kämppä, J. \& Jauhiainen, L. Long-term monitoring of buffer zone efficiency under different cultivation techniques in Boreal conditions. Submitted to Agriculture, Ecosystems and Environment.

Varis, E. 1986. Goat's rue (Galega orientalis Lam.), a potential pasture legume for temperate conditions. Journal Agricultural Science in Finland 58: 83-101.

Virkajärvi, P. \& E. Varis. 1991. The effect of cutting times on goat's rue (Galega orientalis Lam.) leys. Journal of Agricultural Science in Finland. 63: 391-402. 